\title{
Исследование лазерных свойств теллуритных световодов, легированных ионами эрбия
}

\author{
Е.А. Анашкина ${ }^{1,2}$, В.В. Дорофеев ${ }^{2,3}$, С.В. Муравьев ${ }^{1,2^{*}}$, С.Е. Моторин ${ }^{2,3}$, \\ А.В. Андрианов ${ }^{1}$, А.А. Сорокин ${ }^{1,4}$, М.Ю. Коптев ${ }^{1}$, А.В. Ким ${ }^{1}$ \\ ${ }^{1}$ Институт прикладной физики РАН, г. Н. Новгород \\ ${ }^{2}$ Центр лазерной технологии и материаловедения, г. Москва \\ ${ }^{3}$ Институт химии высокочистых веществ им. Г. Г. Девятых РАН, г. Н. Новгород \\ ${ }^{4}$ Нижегородский государственный университет им. Н. И. Лобачевского, г. Н. Новгород \\ "E-mail: sergey-muravyev@yandex.ru
}

DOI:10.31868/RFL2018.53-54

Лазерные источники в диапазоне 2-3 мкм представляют интерес для многих научно-технических задач. Активные волокна на основе высокочистых теллуритных стекол являются перспективными материалами для создания таких источников. Волокна с высокой концентрацией ионов эрбия в сердцевине $\left(1,06 \cdot 10^{21} \mathrm{~cm}^{-3}\right)$ и с двумя отражающими оболочками были изготовлены из высокочистых стекол $\mathrm{TeO}_{2}-\mathrm{ZnO}-\mathrm{La}_{2} \mathrm{O}_{3}-\mathrm{Na}_{2} \mathrm{O}$ с низким поглощением гидроксильных групп (менее $0,01 \mathrm{~cm}^{-3}$ в максимуме полосы $\sim 3,3$ мкм). Для исследований использовали образцы световодов с диаметрами сердцевины 10 мкм, внешней оболочки 100 мкм, с защитным полимерным покрытием. Исследовались генерационные свойства электронного перехода ${ }^{4} \mathrm{I}_{11 / 2} \rightarrow{ }^{4} \mathrm{I}_{13 / 2}$ на длине волны около 2,7 мкм при диодной накачке перехода ${ }^{4} \mathrm{I}_{15 / 2} \rightarrow{ }^{4} \mathrm{I}_{11 / 2}$ на длине волны 0,975 мкм (см. рис. 1(a)).

На рис. 1(б) приведены результаты измерений спектров люминесценции в световоде длиной 5 см с диаметром сердцевины 10 мкм. На основе полученных данных были оценены сечения испускания и поглощения, которые затем использовались при моделировании лазерной генерации в двухцветной каскадной схеме на длинах волн 2,7 и 1,6 мкм и для генерации только на длине волны 2,7 мкм при накачке в первую оболочку. Численно была показана возможность лазерной генерации в обеих схемах. Оптимальная длина активного волокна составила $\mathrm{L}=20$ см при коэффициенте отражения выходного зеркала резонатора $\mathrm{R}_{\text {out }}=80 \%$. Порог генерации составил $\sim 1,5$ Вт, максимальная дифференциальная эффективность - 20\% (см. рис. 1(в)). Использование двухцветной каскадной схемы позволяет осуществить управление населенностью уровня ${ }^{4} \mathrm{I}_{13 / 2}$ и уменьшить паразитные термооптические эффекты. 

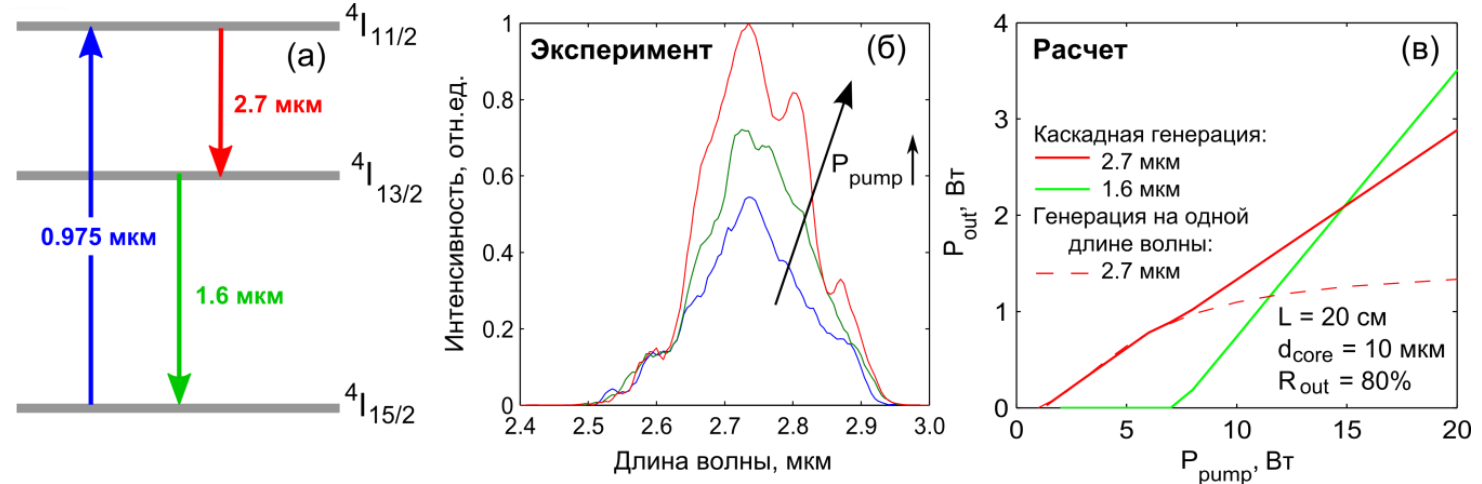

Рис. 1. (а) Упрощенная схема энергетических уровней ионов $\mathrm{Er}^{3+}$, (б) экспериментально измеренные спектры люминесценции на переходе ${ }^{4} \mathrm{I}_{11 / 2} \rightarrow{ }^{4} \mathrm{I}_{13 / 2}$, (в) расчетные зависимости выходной мощности лазерного излучения от мощности накачки.

Работа выполнена при поддержке РНФ (грант № 17-12-01324). 